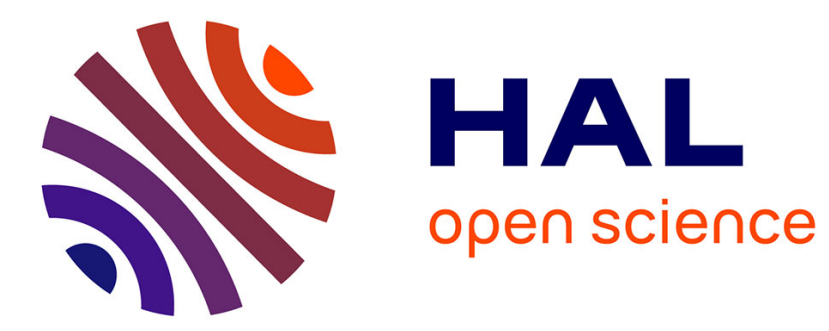

\title{
Synthesis and performance of Sr1.5LaxMnO4 as cathode materials for intermediate temperature solid oxide fuel cell
}

\author{
Sun Li-Ping, Qiang Li, Zhao Hui, Zhang Guo-Ying, Lin Nan, Jean-Paul \\ Viricelle, Christophe Pijolat
}

\section{To cite this version:}

Sun Li-Ping, Qiang Li, Zhao Hui, Zhang Guo-Ying, Lin Nan, et al.. Synthesis and performance of Sr1.5LaxMnO4 as cathode materials for intermediate temperature solid oxide fuel cell. Journal of Power Sources, 2011, 196 (14), pp.5835-589. 10.1016/j.jpowsour.2011.03.016 . hal-00596971

\section{HAL Id: hal-00596971 https://hal.science/hal-00596971}

Submitted on 6 Jun 2011

HAL is a multi-disciplinary open access archive for the deposit and dissemination of scientific research documents, whether they are published or not. The documents may come from teaching and research institutions in France or abroad, or from public or private research centers.
L'archive ouverte pluridisciplinaire HAL, est destinée au dépôt et à la diffusion de documents scientifiques de niveau recherche, publiés ou non, émanant des établissements d'enseignement et de recherche français ou étrangers, des laboratoires publics ou privés. 


\title{
Synthesis and performance of $\mathrm{Sr}_{1.5} \mathrm{La}_{x} \mathrm{MnO}_{4}$ as cathode materials for intermediate temperature solid oxide fuel cell
}

\author{
Sun Li-Ping(1), Li Qiang(1), Huo Li-HuA(1), Zhao Hui(1)*, Zhang GuO-Ying(1), Lin \\ NAN(1), J EAN-PAUl ViriCELle ${ }^{(2)} \dagger$, CHRISTOPHE PIJ OLAT ${ }^{(2)}$ \\ (1) Key Laboratory of Functional Inorganic Material Chemistry, Ministry of Education, \\ School of Chemistry and Materials Science, Heilongjiang University, Harbin 150o80, \\ PR China \\ (2) Ecole Nationale Supérieure des Mines de Saint Etienne, Centre SPIN ; Département \\ MICC ; LPMG -UMR CNRS 5148, 158 Cours Fauriel - 42023 Saint-Étienne Cedex 2, \\ France
}

\begin{abstract}
A-site non-stoichiometric materials $\mathrm{Sr}_{1.5} \mathrm{La}_{x} \mathrm{MnO}_{4}(x=0.35,0.40,0.45)$ are prepared via solid state reaction. The structure of these materials is determined to be tetragonal. Both the lattice volume and the thermal expansion coefficient reduce with the decrease of lanthanum content. On the contrary, the conductivity increases and the maximum value of $13.9 \mathrm{~S} \mathrm{~cm}^{-1}$ is found for $\mathrm{Sr}_{1.5} \mathrm{La}_{0.35} \mathrm{MnO}_{4}$ at $750{ }^{\circ} \mathrm{C}$ in air. AC impedance spectroscopy and DC polarization measurements are used to study the electrode performance. The optimum composition of $\mathrm{Sr}_{1.5} \mathrm{La}_{0.35} \mathrm{MnO}_{4}$ results in $0.25 \Omega \mathrm{cm}^{2}$ area specific resistance (ASR) at $750{ }^{\circ} \mathrm{C}$ in air. The oxygen partial pressure measurement indicates that the charge transfer process is the ratelimiting step of the electrode reactions.
\end{abstract}

Keywords:

Intermediate temperature solid oxide fuel cell (IT-SOFC); Cathode materials; $\mathrm{Sr}_{1.5} \mathrm{La}_{x} \mathrm{MnO}_{4}$; Electrode reaction

\section{Introduction}

Solid oxide fuel cells (SOFCs) attracted more and more substantial interests in recent years, due to their high energy conversion efficiency, ability to use low cost non-precious metal catalysts, fuel flexibility and system compactness compared to other types of fuel cells [1] and [2]. Nowadays, one of the most important research goals is to develop intermediatetemperature solid oxide fuel cell (IT-SOFC). IT-SOFC will solve various problems associated with the high operation temperature $\left(900-1000{ }^{\circ} \mathrm{C}\right)$, such as sealing and thermal degradation. However, a key obstacle to reduced-temperature operation of SOFCs is the poor activity of traditional cathode materials for electrochemical reduction of oxygen [3], [4] and [5]. Therefore, it is critical to develop advanced cathode materials with favorable electrochemical performance at reduced operation temperature.

Recently, many investigations on mixed ionic electronic conductors (MIECs) with $\mathrm{K}_{2} \mathrm{NiF}_{4}$ structure were reported [6], [7], [8], [9], [10], [11], [12], [13], [14], [15] and [16]. These oxides are usually formulated as $\mathrm{A}_{2} \mathrm{BO}_{4}$, which can be described as a series combination of $\mathrm{ABO}_{3}$ perovskite layers alternating with $\mathrm{AO}$ rock-salt layers along the $c$-direction [17]. These compounds can accommodate a significant amount of oxygen non-stoichiometry, due to their unique crystal structure characteristics. It is generally accepted that oxygen ionic conduction

\footnotetext{
* Corresponding author : zhaohuig8@yahoo.com

${ }^{\dagger}$ Corresponding author : viricelle@emse.fr
} 
in $\mathrm{K}_{2} \mathrm{NiF}_{4}$-type compounds may occur via a vacancy mechanism in the perovskite layers or via diffusion of interstitial oxygen in the rock-salt layers, whereas the electronic conduction behavior comes from the p-type electronic conductivity in the perovskite layers [18], [19], [20] and [21]. Previous studies have shown that $\mathrm{A}_{2} \mathrm{BO}_{4}$ oxides possess good thermochemical stability, compatible thermal expansion coefficient with traditional electrolytes, and improved oxygen diffusion and surface exchange coefficients compared with perovskite oxides [22], [23], [20] and [24]. These desirable properties mentioned above make $\mathrm{A}_{2} \mathrm{BO}_{4}$ oxide a promising candidate of cathode material for IT-SOFC. It is known that the content of interstitial oxygen and the oxygen ionic conductivity in these compounds are mainly determined by A-site cations, and the electrical, magnetic and catalytic properties are mainly determined by B-site cations. We consider that this kind of materials will exhibit excellent performance as cathode for SOFC through pertinently choice of A-site and/or B-site elements. Up to now, the researches based on $\mathrm{K}_{2} \mathrm{NiF}_{4}$ type cathode materials are mainly focused on $\mathrm{Ni}$, $\mathrm{Cu}, \mathrm{Co}$ and other rear transition elements on B-site [25] and [26]. Few attentions have been paid to fore transition elements, such as Mn. Munnings et al. prepared $\mathrm{Sr}_{2-x} \mathrm{La}_{x} \mathrm{MnO}_{4+\delta}$ and studied their structure, stability and electrical conductivity. The investigation indicated that $\mathrm{Sr}_{2-x} \mathrm{La}_{x} \mathrm{MnO}_{4+\delta}$ has good thermochemical stability over a wide range of oxygen partial pressures and the thermal expansion coefficient is comparable to the most commonly available electrolyte materials [10]. In a previous study, we reported the cathodic performance of $\mathrm{Sr}_{2-x} \mathrm{La}_{x} \mathrm{MnO}_{4}(x=0.4,0.5,0.6)$ and found that the lowest polarization resistance of $\mathrm{Sr}_{1.4} \mathrm{La}_{0.6} \mathrm{MnO}_{4}$ was $0.39 \Omega \mathrm{cm}^{2}$ at $800{ }^{\circ} \mathrm{C}$ in air [27]. In this paper, a series of A site nonstoichiometric solid solutions, $\mathrm{Sr}_{1.5} \mathrm{La}_{x} \mathrm{MnO}_{4}(x=0.35,0.40,0.45)$ were synthesized via solid state reaction and their electrochemical properties were investigated systematically in relation to the requirement of SOFC cathode.

\section{Experimental}

\section{II.1. Preparation of $\mathrm{Sr}_{1.5} \mathrm{La}_{x} \mathrm{MnO}_{4}(x=0.35,0.40,0.45)$ powder}

$\mathrm{Sr}_{1.5} \mathrm{La}_{x} \mathrm{MnO}_{4}$ powders were prepared by conventional solid state reaction method. The precursors were $\mathrm{La}_{2} \mathrm{O}_{3}, \mathrm{SrCO}_{3}$ and $\mathrm{MnCO}_{3}$. All of the starting materials were analytical reagent. $\mathrm{La}_{2} \mathrm{O}_{3}$ was preheated to $1000{ }^{\circ} \mathrm{C}$ to remove any possible hydroxide and carbonate. $\mathrm{SrCO}_{3}$ and $\mathrm{MnCO}_{3}$ were heated to evaporate the adsorbed water. Stoichiometric amounts of $\mathrm{La}_{2} \mathrm{O}_{3}, \mathrm{SrCO}_{3}$ and $\mathrm{MnCO}_{3}$ powders were intimately mixed with absolute alcohol in an agate mortar and grinded with pestle for $2 \mathrm{~h}$. Then the mixture was calcined at $1000^{\circ} \mathrm{C}$ for $12 \mathrm{~h}$ and subsequently pressed (220 MPa) into pellets and calcined at $1300{ }^{\circ} \mathrm{C}$ for $24 \mathrm{~h}$. The pellets were then crushed and followed by repeated grinding and calcining until complete reaction and uniform composition were achieved.

\section{II.2. Preparation of cathode}

Three electrodes system was fabricated to test the electrochemical properties. $\mathrm{Ce}_{0.9} \mathrm{Gd}_{0.1} \mathrm{O}_{1.95}$ (CGO) powder was obtained from Rhodia Courbevoie (France). The CGO powders were pressed uniaxially at $220 \mathrm{MPa}$ and then sintered at $1400{ }^{\circ} \mathrm{C}$ for $10 \mathrm{~h}$ to form densified pellet. About $200 \mathrm{mg} \mathrm{Sr}{ }_{1.5} \mathrm{La}_{x} \mathrm{MnO}_{4}$ powders were mixed with $0.5 \mathrm{~mL}$ terpineol to form a slurry, and subsequently painted on one side of the CGO pellet, to form working electrode (WE) area of $1.0 \mathrm{~cm}^{2}$. Platinum paste was painted on the other side of the CGO pellet in symmetric configuration, as the counter electrode (CE). A Pt wire was used as reference electrode (RE) and painted on the same side that of the working electrode. The cathode was first heated at $400{ }^{\circ} \mathrm{C}$ for $2 \mathrm{~h}$ to eliminate organic binders, followed by sintering at $1000^{\circ} \mathrm{C}$ for $4 \mathrm{~h}$ in air, with a heating/cooling rate of $3{ }^{\circ} \mathrm{C} \mathrm{min}{ }^{-1}$. The scheme of the cell was illustrated in Reference [28]. The microstructure of the cathode was investigated by scanning electron microscopy (SEM) (Hitachi, S-4700 FEG).

\section{II.3. Characterization}

The phase identification of the synthesized powders was performed with X-ray diffraction instrument (Rigaku, D/MAX-3B). Structure refinements were carried out by the Rieltveld method. The electrical conductivity of the $\mathrm{Sr}_{1.5} \mathrm{La}_{x} \mathrm{MnO}_{4}$ materials was measured by the 
standard four-probe DC method. Measurements were performed from room temperature to $750{ }^{\circ} \mathrm{C}$ with a heating rate of $5{ }^{\circ} \mathrm{C} \mathrm{min}{ }^{-1}$. The thermal expansion of the rectangular specimens was measured from room temperature to $900{ }^{\circ} \mathrm{C}$ in air, using TMA system (SETSYS Evolution) with a heating rate of $5{ }^{\circ} \mathrm{C} \mathrm{min}^{-1}$. The impedance spectra were recorded over the frequency range $1 \mathrm{MHz}$ to $0.1 \mathrm{~Hz}$ using Autolab PGStat30. The measurements were performed at $\mathrm{OCV}$ as a function of temperature $\left(550-750^{\circ} \mathrm{C}\right.$ ) and oxygen partial pressure (in an $\mathrm{N}_{2} / \mathrm{O}_{2}$ mixed atmosphere). The DC polarization experiments were performed by the chronoampermetry methods, as that explained in Reference [29].

III. Results and discussion

\section{III.1. XRD analysis}

Figure 1 shows the room temperature XRD patterns of $\mathrm{Sr}_{1.5} \mathrm{La}_{x} \mathrm{MnO}_{4}(x=0.30,0.35,0.40$, 0.45). The refined cell parameters are listed in Table 1 . All the diffraction peaks can be well indexed as $\mathrm{K}_{2} \mathrm{NiF}_{4}$ tetragonal structure with the space group $I 4 / \mathrm{mmm}$. It was observed that the main diffraction peaks of $\mathrm{Sr}_{1.5} \mathrm{La}_{x} \mathrm{MnO}_{4}$ shifted gradually to higher values of $2 \theta$ with the increases of La cation deficiency, which indicates the shrinkage of cell lattice parameters. When the value of $x$ decreased to 0.30 , however, some impurity phases were detected. This result suggests that La cation deficiency fraction is limited to approximately 0.35 for $\mathrm{Sr}_{1.5} \mathrm{La}_{x} \mathrm{MnO}_{4}$ material. The lattice shrinkage can be attributed to the following two factors: (1) with the increase of La cation deficiency, part of the $\mathrm{Mn}$ valence changed from $\mathrm{Mn}^{3+}$ to $\mathrm{Mn}^{4+}$ due to the electroneutrality condition. According to the valence-bond theory, the $\mathrm{Mn}-\mathrm{O}$ bond strength will increase and bond-length decrease in this case; (2) the loss of lattice oxygen and the formation of oxygen vacancies are enhanced with the increase of La cation deficiency.

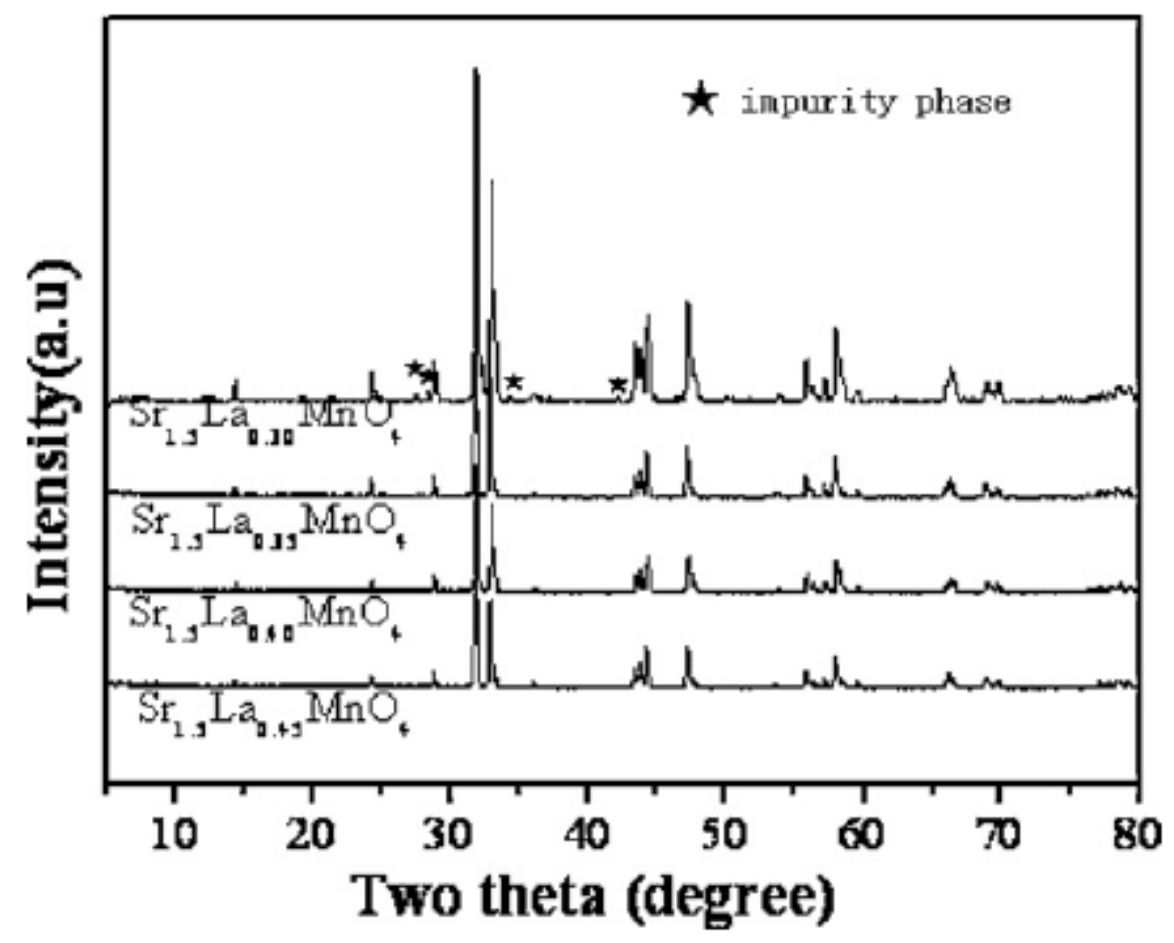

Figure 1:. XRD patterns of $\mathrm{Sr}_{1.5} \mathrm{La}_{x} \mathrm{MnO}_{4}(x=0.30,0.35,0.40,0.45)$ sintered at $1000{ }^{\circ} \mathrm{C}$ in air.

The high temperature chemical stability of $\mathrm{Sr}_{1.5} \mathrm{La}_{x} \mathrm{MnO}_{4}$ material was investigated. Figure 2 presents the XRD patterns of $\mathrm{Sr}_{1.5} \mathrm{La}_{0.35} \mathrm{MnO}_{4}$ and CGO mixtures after heat-treated at $1000{ }^{\circ} \mathrm{C}$ for $4 \mathrm{~h}$. Obviously the CGO and $\mathrm{Sr}_{1.5} \mathrm{La}_{0.35} \mathrm{MnO}_{4}$ remained their structures unchanged. There were no new peaks identifiable or shift of XRD peaks observed in the patterns, indicating that there is no reaction and/or inter-diffusion of elements occurred between $\mathrm{Sr}_{1.5} \mathrm{La}_{0.35} \mathrm{MnO}_{4}$ and CGO. Thus, it is reasonable to conclude that $\mathrm{Sr}_{1.5} \mathrm{La}_{0.35} \mathrm{MnO}_{4}$ is a chemically stable cathode material for CGO electrolyte. 
Table 1. Structural parameters of $\mathrm{Sr}_{1.5} \mathrm{La}_{x} \mathrm{MnO}_{4}$ obtained from Rietveld refinements of powder X-ray diffraction data.

\begin{tabular}{|l|l|l|l|l|}
\hline$x$ & 0.35 & 0.40 & 0.45 & 0.50 \\
\hline$a(\mathrm{~nm})$ & 038.441 & 038.505 & 038.518 & 038.637 \\
\hline$c(\mathrm{~nm})$ & 123.940 & 124.050 & 124.070 & 124.370 \\
\hline$V\left(\times 10^{3} \mathrm{~nm}^{3}\right)$ & 183.150 & 183.920 & 184.070 & 185.660 \\
\hline
\end{tabular}

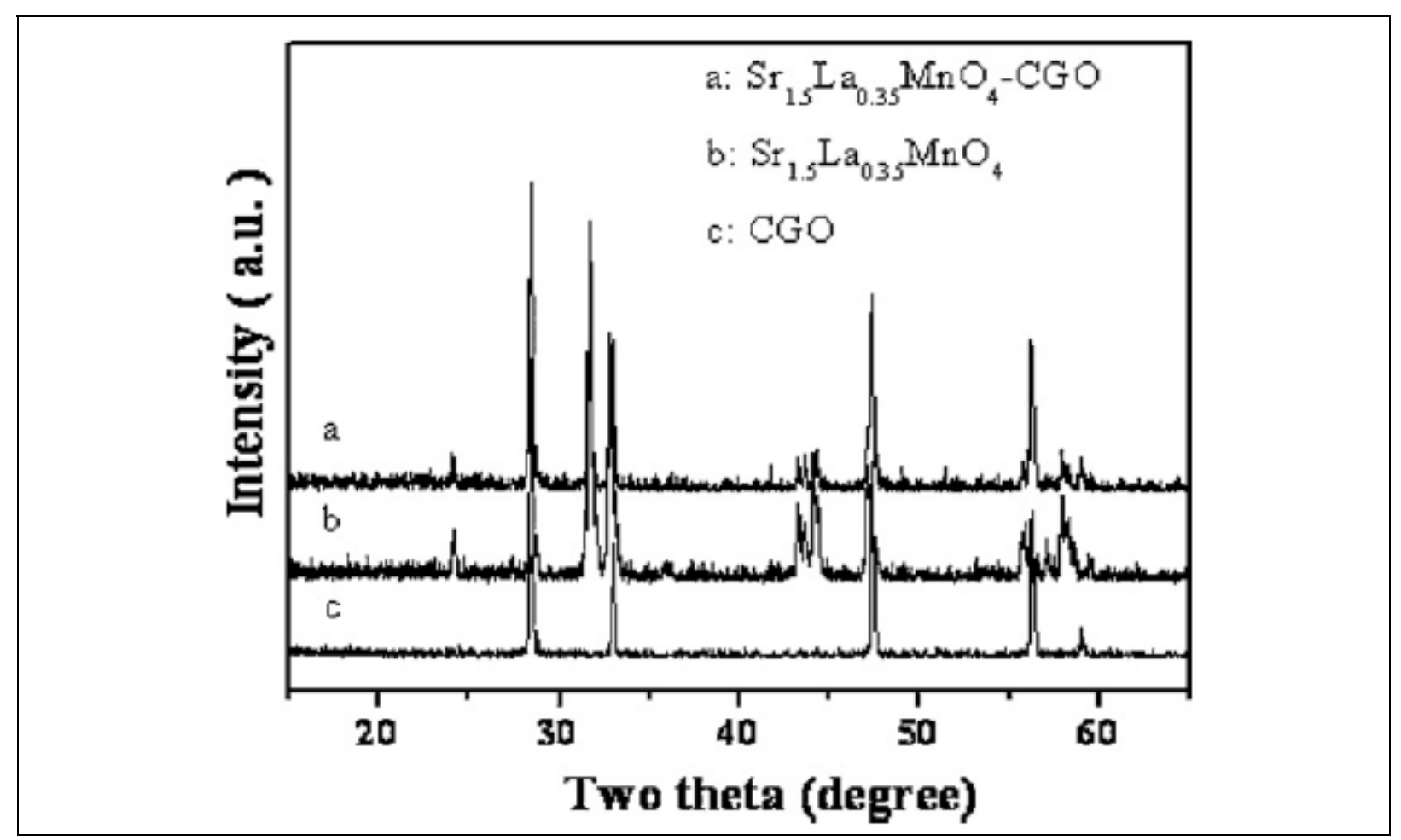

Figure 2: XRD patterns of $\mathrm{Sr}_{1.5} \mathrm{La}_{0.35} \mathrm{MnO}_{4}, \mathrm{CGO}$ and $\mathrm{Sr}_{1.5} \mathrm{La}_{0.35} \mathrm{MnO}_{4}-\mathrm{CGO}$ powders.

\section{III.2. Thermal expansion}

The thermal expansion behaviors of $\mathrm{Sr}_{1.5} \mathrm{La}_{x} \mathrm{MnO}_{4}(x=0.35,0.40,0.45)$ specimens at 300$900{ }^{\circ} \mathrm{C}$ in air are shown in Figure 3. The dilatometric curves of these oxides can be adequately approximated by linear dependences in this temperature range. The average thermal expansion coefficient (TEC) value was found to decrease with the increase of La cation deficiency. The TEC values for $\mathrm{Sr}_{1.5} \mathrm{La}_{0.45} \mathrm{MnO}_{4}, \mathrm{Sr}_{1.5} \mathrm{La}_{0.40} \mathrm{MnO}_{4}$ and $\mathrm{Sr}_{1.5} \mathrm{La}_{0.35} \mathrm{MnO}_{4}$ are $16.1 \times 10^{-6}, 15.5 \times 10^{-6}$ and $14.5 \times 10^{-6} \mathrm{~K}^{-1}$, respectively. This can be understood by considering the inversely proportional relationship between TEC and the bonding energy of ions in the lattice [30]. According to the refinement results (Table 1), both the cell volume and lattice parameters decrease with the increase of La cation deficiency. This will strengthen the $\mathrm{M}-\mathrm{O}$ bond and result in the increase of bonding energy. It is clear that the TEC values of $\mathrm{Sr}_{1.5} \mathrm{La}_{x} \mathrm{MnO}_{4}$ decrease with the increase of La cation deficiency and the TEC value of $\mathrm{Sr}_{1.5} \mathrm{La}_{0.35} \mathrm{MnO}_{4}$ is much closer to that of CGO $\left(\sim 13.1 \times 10^{-6} \mathrm{~K}^{-1}\right)$. This implies that $\mathrm{Sr}_{1.5} \mathrm{La}_{0.35} \mathrm{MnO}_{4}$ might be more suitable as a cathode based on CGO electrolyte for IT-SOFC.

\section{III.3. Electrical conductivity}

Arrhenius plots for the electrical conductivity of $\mathrm{Sr}_{1.5} \mathrm{La}_{x} \mathrm{MnO}_{4}(x=0.35,0.40,0.45)$ are given in Figure 4. A linear relationship between $\ln (\sigma T)$ and $1 / T$ was found for all samples. The calculated Ea values ranged between 0.2 and $0.3 \mathrm{eV}$, indicating a small polaron hopping mechanism. As shown in Figure 4, the electrical conductivity increased and the activation energy decreased with the increase of La cation deficiency. This phenomenon can be ascribed not only to the steady increase of p-type charge carriers with La cation deficiency, but also to 
the increased overlapping of the atomic orbits between adjacent Mn atoms. Based on XRD refinement, cell parameters a and c decrease with increasing La cation deficiency.

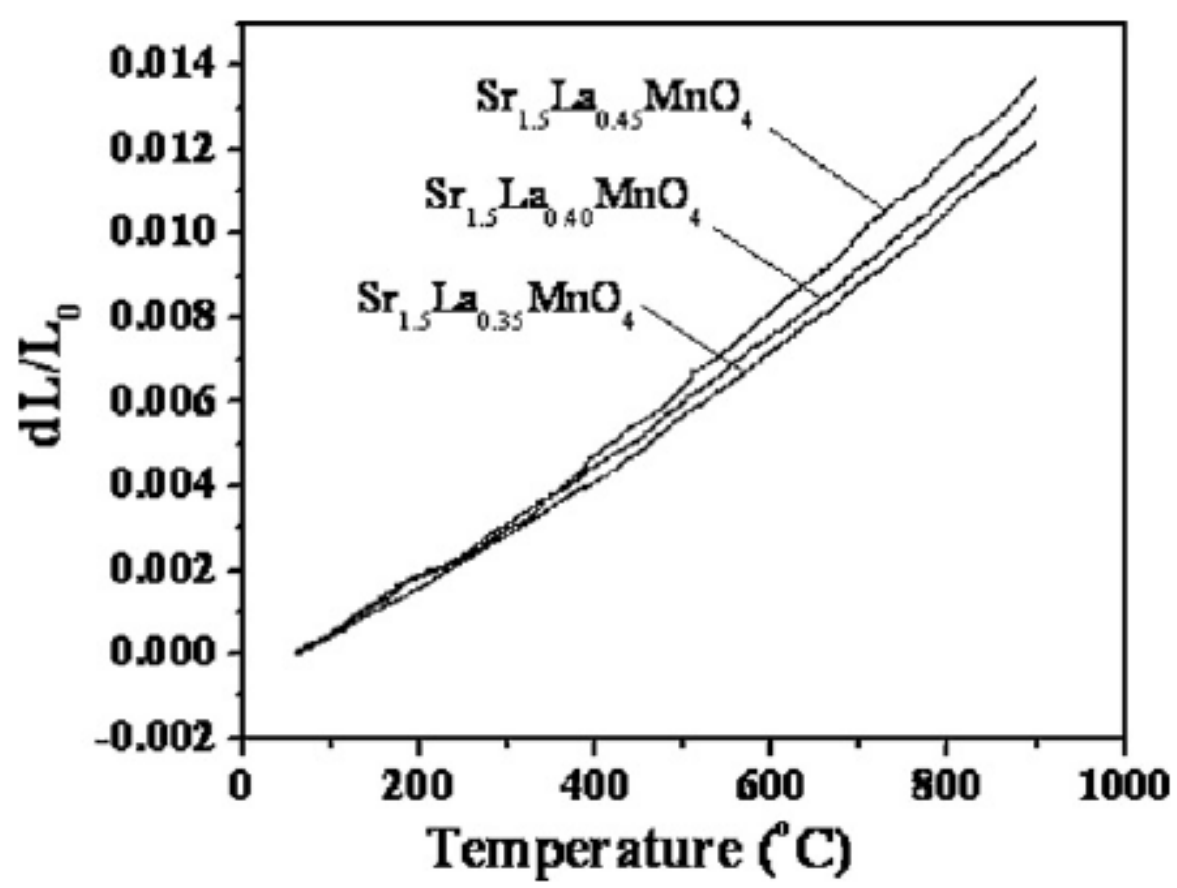

Figure 3: Thermal expansion curves of $\mathrm{Sr}_{1.5} \mathrm{La}_{\mathrm{x}} \mathrm{MnO}_{4}$ materials.

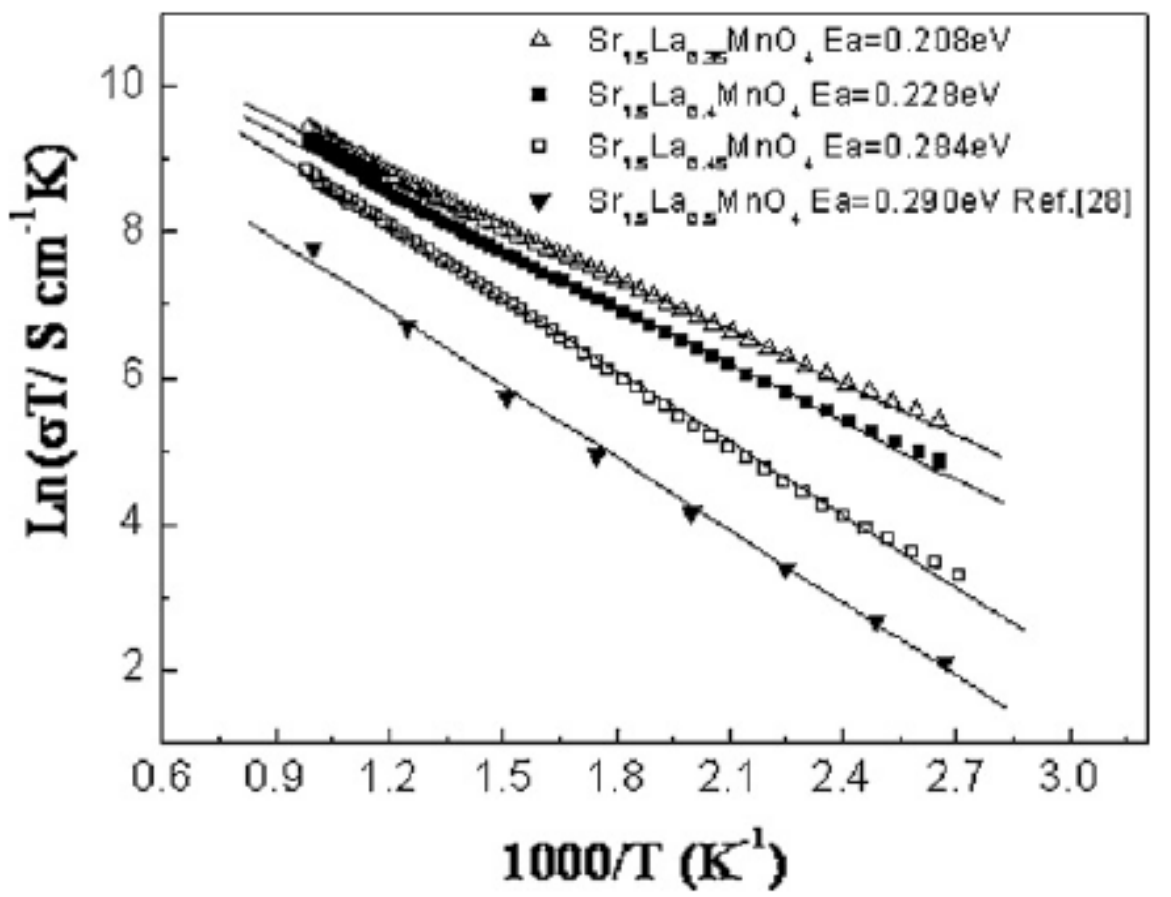

Figure 4: Temperature dependence of the electrical conductivity for $\mathrm{Sr}_{1.5} \mathrm{La}_{\mathrm{x}} \mathrm{MnO}_{4}(\mathrm{x}=0.35,0.40,0.45,0.5)$ in air.

As a result, the bond length of $\mathrm{Mn}^{3+}-\mathrm{O}^{2-}-\mathrm{Mn}^{4+}$ reduced and the overlapping of the atomic orbits between the adjacent Mn was promoted, which subsequently increased the liability of the migration of the charge carriers. The highest electrical conductivity $13.9 \mathrm{~S} \mathrm{~cm}^{-1}$ was 
obtained at $750{ }^{\circ} \mathrm{C}$ in air for $\mathrm{Sr}_{1.5} \mathrm{La}_{0.35} \mathrm{MnO}_{4}$, which is much higher than that of the stoichiometric $\mathrm{Sr}_{2-x} \mathrm{La}_{x} \mathrm{MnO}_{4+\delta}$ oxides [27].

III.4. Microstructure of cathode

The microstructure of the sintered electrode is one of the most important factors to influence cathode performance. Figure 5 shows surface and cross-section morphologies of $\mathrm{Sr}_{1.5} \mathrm{La}_{0.35} \mathrm{MnO}_{4}$ cathode on CGO electrolyte after sintered at $1000{ }^{\circ} \mathrm{C}$ for $4 \mathrm{~h}$ in air. It can be seen (Figure 5a) that $\mathrm{Sr}_{1.5} \mathrm{La}_{0.35} \mathrm{MnO}_{4}$ electrode exhibits a homogeneous porous microstructure. The electrode particles $(500 \mathrm{~nm}$ in average grain size) appear to form continuous network, which is beneficial for the gas transportation and formation of the electronic conducting network within the cathode. From the cross-sectional view (Figure 5b), it can be seen that CGO electrolyte and cathode adhered well to each other with a cathode thickness of about $15 \mu \mathrm{m}$. No delamination occurs at the electrolyte-cathode interface after cell testing.
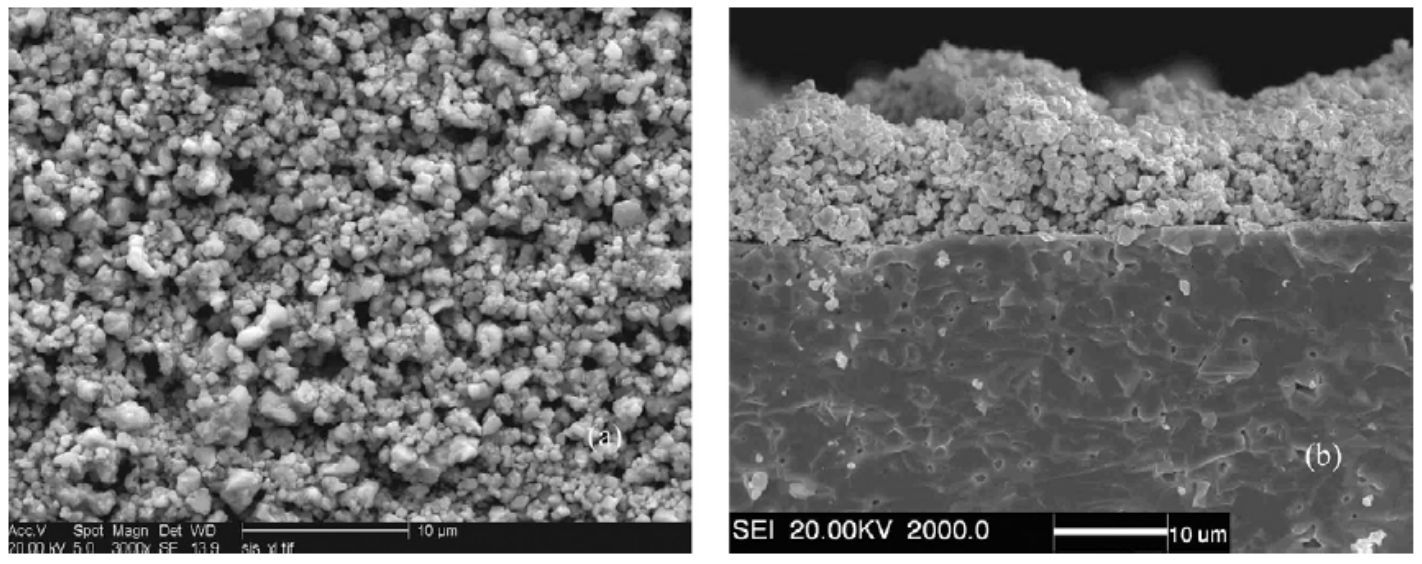

Figure 5: The SEM images of $\mathrm{Sr}_{1.5} \mathrm{La}_{0.35} \mathrm{MnO}_{4}$ electrode sintered at $1000{ }^{\circ} \mathrm{C}(a)$ and the cross-section image of the test cell (b).

\section{III.5. Electrochemical performance}

The performance of $\mathrm{Sr}_{1.5} \mathrm{La}_{x} \mathrm{MnO}_{4}$ cathode for oxygen reduction was studied by EIS in three electrode system. Figure 6 shows the temperature dependence of the electrode polarization resistance of $\mathrm{Sr}_{1.5} \mathrm{La}_{x} \mathrm{MnO}_{4}$ cathode. The polarization resistance values reduced with the increase of La cation deficiency over the entire examined temperature range. $\mathrm{Sr}_{1.5} \mathrm{La}_{0.35} \mathrm{MnO}_{4}$ gave the lowest polarization resistance value $\left(\sim 0.25 \Omega \mathrm{cm}^{2}\right)$ at $750{ }^{\circ} \mathrm{C}$ in air, which is about 1/6 that of $\mathrm{Sr}_{1.4} \mathrm{La}_{0.6} \mathrm{MnO}_{4}$. The superior electrochemical performance of $\mathrm{Sr}_{1.5} \mathrm{La}_{0.35} \mathrm{MnO}_{4}$ cathode is ascribed to the following reasons. It is proved that the oxygen vacancies were indeed beneficial to the oxygen reduction reaction (ORR) [31] and [32]. The creation of oxygen vacancies with the increase of La cation deficiencies in $\mathrm{Sr}_{1.5} \mathrm{La}_{x} \mathrm{MnO}_{4}$ facilitated oxygen ion both diffusion within the oxide bulk and surface diffusion of the diassociative adsorbed oxygen on the electrode; In addition, the conductivity of the cathode material was improved, which will improve the cathodic electrochemical performance as well.

In order to further understand the ORR mechanism on the electrodes, impedance measurements were done as a function of oxygen partial pressure. Figure 7 shows the impedance spectra of $\mathrm{Sr}_{1.5} \mathrm{La}_{0.35} \mathrm{MnO}_{4}$ cathode measured at $750{ }^{\circ} \mathrm{C}$ under various oxygen partial pressures $\left(\underline{P}_{\mathrm{O}_{2}}\right)$. The value between the high frequency $x$-axis intercept and the low frequency one is attributed to the total polarization resistance $\left(R_{\mathrm{p}}\right)$ of $\mathrm{Sr}_{1.5} \mathrm{La}_{0.35} \mathrm{MnO}_{4}$ cathode. As can be seen, the impedance spectra contain two separable depressed arcs, suggesting that at least two different electrode processes limited the oxygen reduction reactions. In order to separate the different contributions, an equivalent circuit with two distributed elements was used to fit the data. As shown in Figure $7, R_{\mathrm{el}}$ is the combination of electrolyte resistance, electrode ohmic resistance, lead resistance and contact resistance between cell and Pt mesh, CPE is the constant phase element in parallel with a resistance $(R), R_{\mathrm{H}}$ and $R_{\mathrm{L}}$ are the 
resistance corresponding to the high-frequency and low-frequency arc, respectively. The dependence of polarization resistance on oxygen partial pressure was shown in Figure 8. As we know, the ASR of the electrode varied with the oxygen partial pressure according to the following law:

$[A S R]=[A S R]^{0}\left(P_{\mathrm{O}_{2}}\right)^{n}$

For different process, there is a unique $n$ value. A value of $0,0.25,0.5$ and 1 is associated with the following reactions, respectively[33].

$\begin{array}{ll}\mathrm{n}=1 & O_{2}(g) \Leftrightarrow O_{2, a d s .} \\ \mathrm{n}=0.5 & O_{2, a d s .} \Leftrightarrow 2 O_{a d s .} \\ \mathrm{n}=0.25 & O_{a d s .}+2 e ́+V_{O . .} \Leftrightarrow O_{O}^{x} \\ \mathrm{n}=\mathrm{O} & O_{T P B}^{2-}+V_{O} . \Leftrightarrow O_{O}^{x}\end{array}$

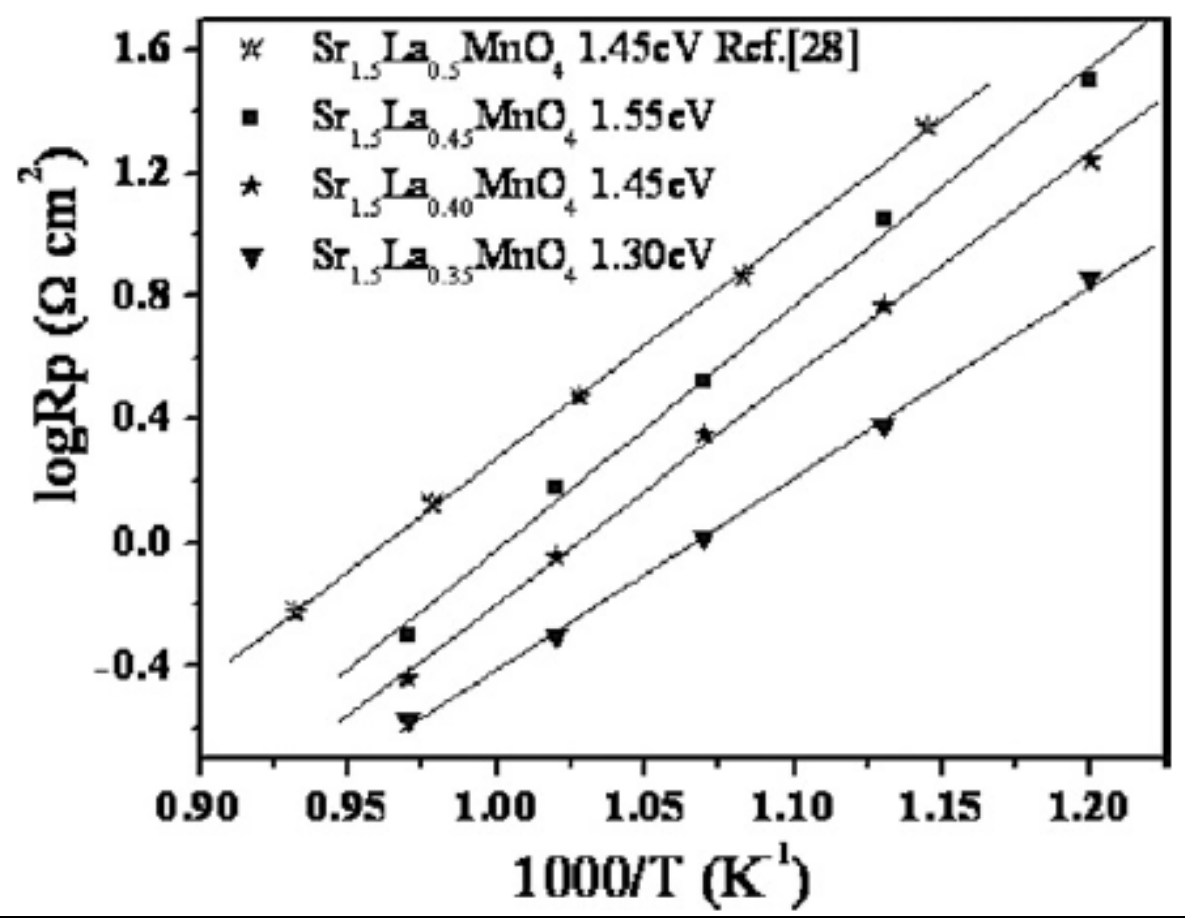

Figure 6: Arrhenius plot of the polarization resistances of $\mathrm{Sr}_{1.5} \mathrm{La}_{\mathrm{x}} \mathrm{MnO}_{4}(\mathrm{x}=0.35,0.40,0.45,0.5)$ electrodes.

Our results indicated a complex relationship between the polarization resistance and the oxygen partial pressure. At low oxygen partial pressure (less than $3.03 \mathrm{kPa}$ ), $n$ value is near zero for $R_{\mathrm{H}}(n=0.01)$, which is associated with the oxygen ion transfer from the TPB to the electrolyte; for $R_{\mathrm{L}}$ the value is 0.24 , which is related to charge-transfer reaction at the triplephase boundary (see Figure 8). When the oxygen partial pressure is above $3.03 \mathrm{kPa}$, however, $n$ value is 0.22 for $R_{\mathrm{H}}$, which is associated with the charge-transfer reaction, and 0.51 for $R_{\mathrm{L}}$, which is related to surface diffusion of the dissociative adsorbed oxygen at the TPBs (see Figure 8). Compared with the fitting results of Figure 7 and Figure 8, we found that at low oxygen partial pressure (less than $3.03 \mathrm{kPa}$ ), the magnitude of $R_{\mathrm{L}}$ is larger than $R_{\mathrm{H}}$; at high oxygen partial pressure (higher than $3.03 \mathrm{kPa}$ ) however, the magnitude of $R_{\mathrm{H}}$ is larger than $R_{\mathrm{L}}$. So we can draw a conclusion that the charge transfer reaction is the major rate-limiting step in the whole range of measuring oxygen partial pressure. Compared to the previous result of the stoichiometric compound $\mathrm{Sr}_{2-x} \mathrm{La}_{x} \mathrm{MnO}_{4}(x=0.4,0.5,0.6)$, with which the charge transfer reaction is the rate limiting step (Reference 27), it was found that the generation of La cation deficiency promoted the ORR reaction, whereas the reaction mechanism remain unchanged. 


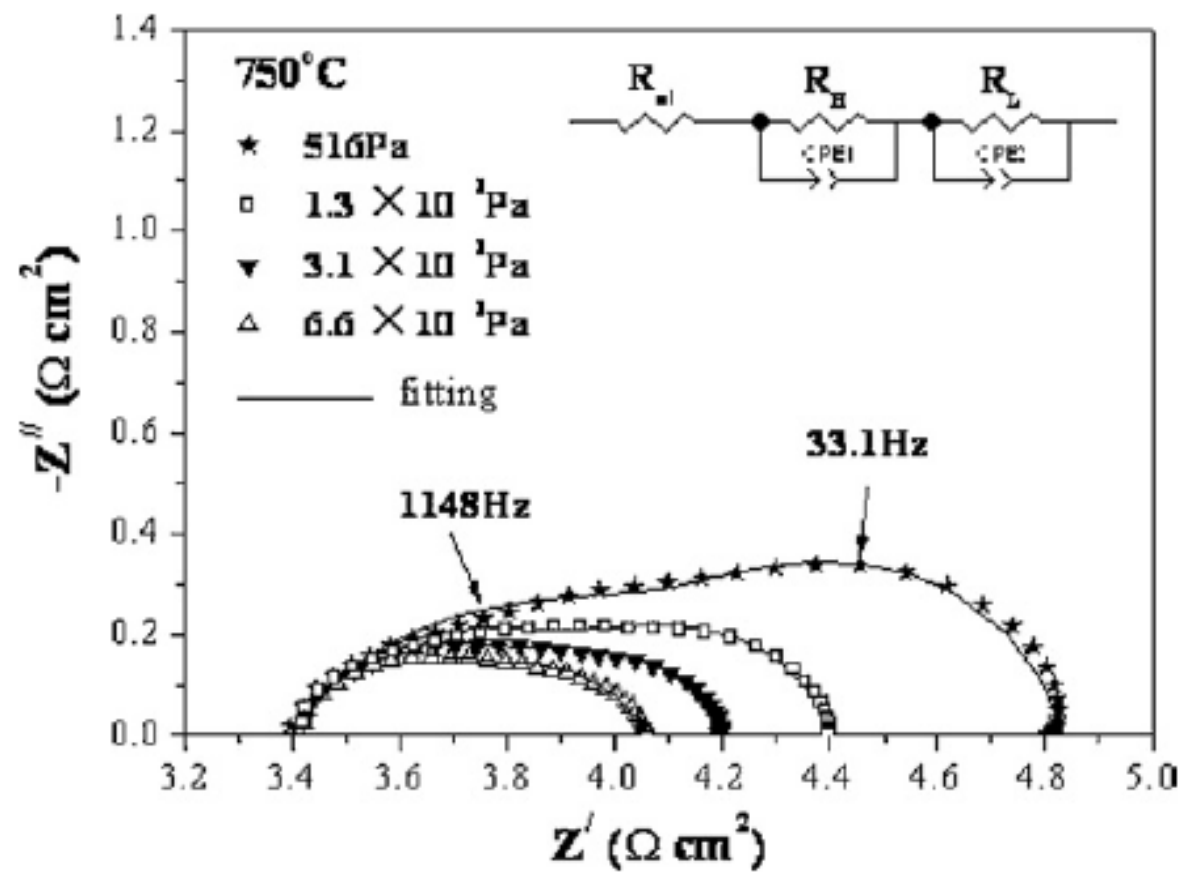

Figure 7: Impedance spectra of $\mathrm{Sr}_{1.5} \mathrm{La}_{0.35} \mathrm{MnO}_{4}$ cathode on $\mathrm{CGO}$ electrolyte measured at $750{ }^{\circ} \mathrm{C}$ under various oxygen partial pressures.

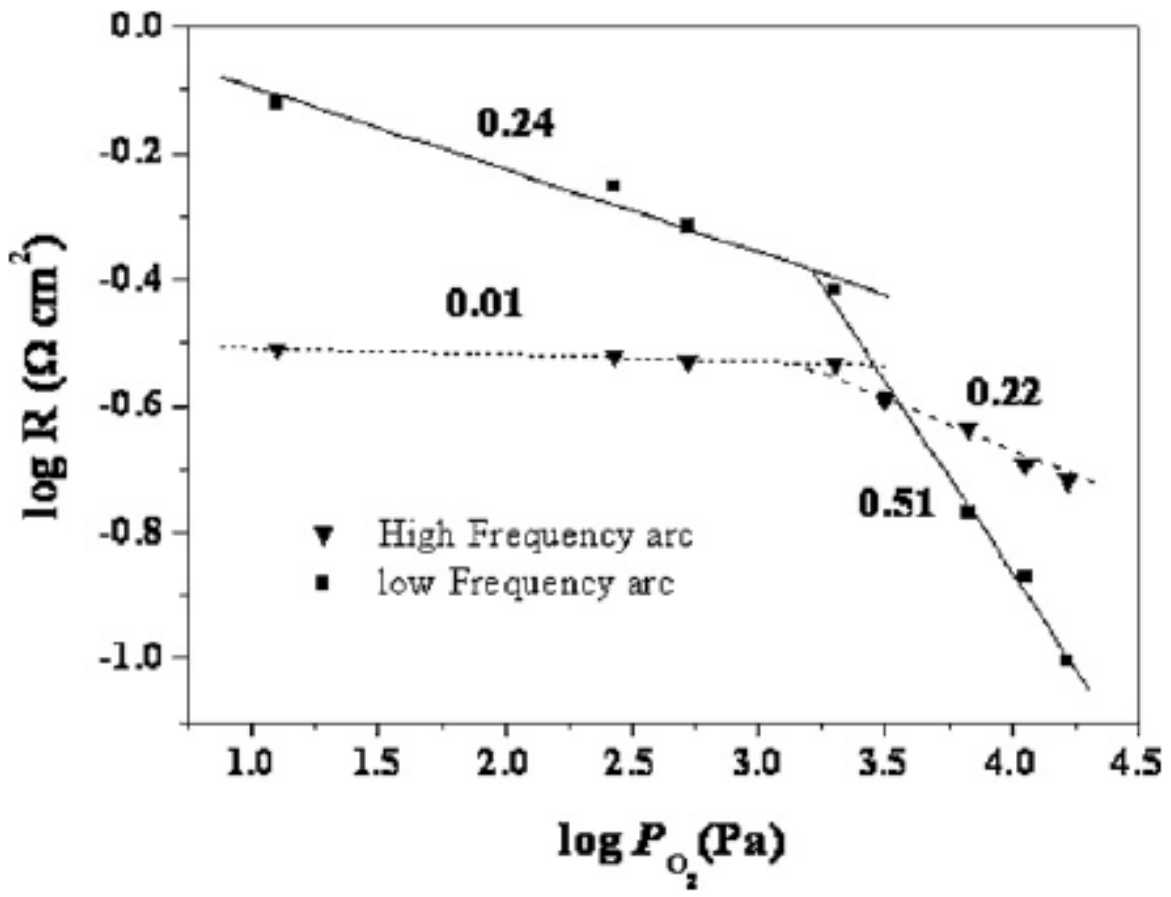

Figure 8: Curves of polarization resistances vs. $\mathrm{P}_{\mathrm{O} 2}$ for $\mathrm{Sr}_{1.5} \mathrm{La}_{0.35} \mathrm{MnO}_{4}$ electrode at $750^{\circ} \mathrm{C}$.

Cathodic overpotential is an important component of electrode performance. Figure 9 presents the typical overpotential curves of $\mathrm{Sr}_{1.5} \mathrm{La}_{0.35} \mathrm{MnO}_{4}$ cathode as a function of current density measured at different temperatures in air. It was observed that the cathodic overpotential decreased with an increase of the measurement temperature, indicating that the catalysis property was improved with the temperature. The polarization overpotential, $49 \mathrm{mV}$ was obtained for $\mathrm{Sr}_{1.5} \mathrm{La}_{0.35} \mathrm{MnO}_{4}$ cathode at a current density of $100 \mathrm{~mA} \mathrm{~cm}{ }^{-2}$ at $750{ }^{\circ} \mathrm{C}$ in air. This value is better than that of the reported $\mathrm{Sr}_{1.4} \mathrm{La}_{0.6} \mathrm{MnO}_{4+\delta}$ materials in literature [27]. This 
result is understandable, considering the presence of large amount of oxygen vacancies generated by the A-site La cation deficiencies in the lattice. Oxygen vacancies can promote the mobility of the oxygen ions. Therefore, the amount of absorbed oxygen on the electrode surface and the migration of oxygen to the TPB or diffusion to the electrode/electrolyte interface can be strongly enhanced.

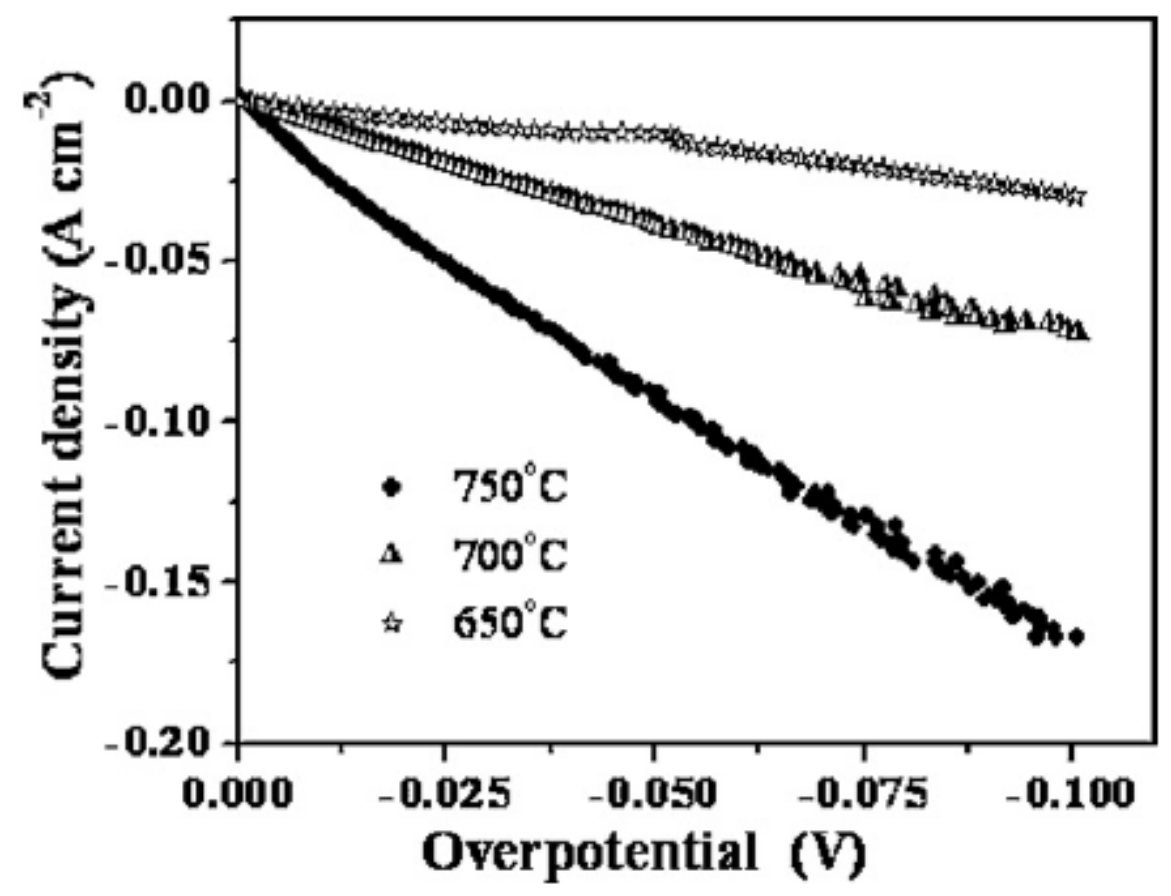

Figure 9: The overpotential-current density curves for $\mathrm{Sr}_{1.5} \mathrm{La}_{0.35} \mathrm{MnO}_{4}$ electrode measured at various temperatures in air.

\section{Conclusions}

$\mathrm{Sr}_{1.5} \mathrm{La}_{x} \mathrm{MnO}_{4}(x=0.35,0.40,0.45)$ oxides have been synthesized by solid state reaction and assessed for possible use in SOFCs. The conductivity of $\mathrm{Sr}_{1.5} \mathrm{La}_{0.35} \mathrm{MnO}_{4}$ is about $13.9 \mathrm{~S} \mathrm{~cm}^{-1}$ at $750{ }^{\circ} \mathrm{C}$ in air. $\mathrm{Sr}_{1.5} \mathrm{La}_{0.35} \mathrm{MnO}_{4}$ cathode forms good contact with CGO electrolyte after sintering at $1000{ }^{\circ} \mathrm{C}$ for $4 \mathrm{~h}$. No chemical reaction was found between $\mathrm{Sr}_{1.5} \mathrm{La}_{0.35} \mathrm{MnO}_{4}$ electrode and CGO electrolyte. The reaction rate limiting step for oxygen reduction on the electrode is the charge transfer process. The lowest $\mathrm{Rp}$ value was achieved for $\mathrm{Sr}_{1.5} \mathrm{La}_{0.35} \mathrm{MnO}_{4}\left(0.25 \Omega \mathrm{cm}^{2}\right)$ at $750^{\circ} \mathrm{C}$ and the highest current density is $100 \mathrm{~mA} \mathrm{~cm}^{-2}$ at overpotential of $49 \mathrm{mV}$.

\section{Acknowledgements}

The Project was supported by National Natural Science Foundation of China (51072048), Research Project of New Century Excellent Talents in University (NCET-06-0349), Heilongjiang Educational Department (GZo9A204, 1152Go27, 11531274, 11531285).

\section{References}

[1] J.C. Ruiz-Morales, J. Canales-Vazquez, C. Savaniu, D. Marrero-Lopez, W. Zhou and J.T.S. Irvine, Nature 439 (2) (2006), p. 568.

[2] Y.-H. Huang, R.I. Dass, Z.-L. Xing, J.B. Goodenough, Science 312 (2006) 254.

[3] N.P. Brandon, S. Skinner, B.C.H. Steel, Rev. Mater. Sci. 33 (2003) 183.

[4] F.S. Baumann, J. Fleig, H.-U. Habermeier, J. Maier, Solid State Ionics 177 (2006) 3187.

[5] K.T. Lee, A. Manthiram, J. Electrochem. Soc. 152 (1) (2005) A197.

[6] V. Dusastre, J.A. Kilner, Solid State Ionics 126 (1999) 163.

[7] A.J. Jennings, S.J. Skinner, Solid State Ionics 152-153 (2002) 663. 
[8] X. Huang, L. Pei, Z. Liu, Z. Lu, Y. Sui, Z. Qian, W. Su, J. Alloys Compd. 345 (2002) 265.

[9] J. Xu, X. Huang, Z. Lu, Y. Zhang, X. Ge, W. Su, Acta Chim. Sin. 64 (2006) 449.

[10] C.N. Munnings, S.J. Skinner, G. Amow, P.S. Whitfield, I.J. Davidson, Solid State Ionics 177 (2006) 1849.

[11] V.V. Kharton, E.V. Tsipis, A.A. Yaremchenko, J.R. Frade, Solid State Ionics 166 (2004) 327.

[12] S. Li, Z. Lu, X. Huang, B. Wei, W. Su, J. Phys. Chem. Solids 68 (2007) 1707.

[13] C. Lalanne, G. Prosperi, J.M. Bassat, F. Mauvy, S. Fourcade, P. Stevens, M. Zahid, S. Diethelm, J. Van Herle, J.C. Grenier, J. Power Sources 185 (2008) 1218.

[14] H. Zhao, F. Mauvy, C. Lalanne, J.M. Bassat, S. Fourcade, J.C. Grenier, Solid State Ionics 179 (2008) 2000.

[15] M.L. Fontaine, C. Laberty-Robert, F. Ansart, P. Tailhades, J. Power Sources 156 (2006) 33 .

[16] Q. Li, H. Zhao, L.H. Huo, L. Sun, X.L. Cheng, J.C. Grenier, Electrochem. Commun. 9 (2007) 1508.

[17] G.L. Flem, G. Demazeau, P. Hagenmuller, J. Solid State Chem. 44 (1982) 82.

[18] V.V. Kharton, A.P. Viskup, A.V. Kovalevsky, E. Naumovich, F.M.B. Marques, Solid State Ionics 143 (2001) 337.

[19] L. Minervini, R.W. Grimes, J.A. Kilner, K.E. Sickafus, J. Mater. Chem. 10 (2000) 2349.

[20] S.J. Skinner, J.A. Kilner, Solid State Ionics 135 (2000) 709.

[21] E. Boehm, J.M. Bassat, P. Dordor, F. Mauvy, J.C. Grenier, P. Stevens, Solid State Ionics 176 (2005) 2717.

[22] M. Al Daroukha, V.V. Vashook, H. Ullmann, F. Tietz, I.A. Raj, Solid State Ionics 158 (2003) 141.

[23] H.W. Nie, T.L. Wen, S.R. Wang, Y.S. Wang, U. Guth, V. Vashook, Solid State Ionics 177 (2006) 1929.

[24] E. Boehm, J.M. Bassat, M.C. Steil, P. Dordor, F. Mauvy, J.C. Grenier, Solid State Sci. 5 (2003) 973.

[25] Y. Cao, H.T. Gu, H. Chen, Y.F. Zheng, M. Zhou, L.C. Guo, J. Int. Hydrogen Energy 35 (2010) 5594.

[26] X.F. Ding, X. Kong, X. Wang, J.G. Jiang, C. Cui, J. Alloys Compd. 502 (2010) 472.

[27] L.P. Sun, L.H. Huo, H. Zhao, Q. Li, C. Pijolat, J. Power Sources 179 (2008) 96.

[28] Q. Li, Y. Fan, H. Zhao, L.H. Huo, Chin. J. Inorg. Chem. 22 (11) (2006) 2025.

[29] H. Zhao, L.H. Huo, L.P. Sun, L.J. Yu, S. Gao, J.G. Zhao, Mater. Chem. Phys. 88 (2004) 160.

[30] A.R. Ruffa, J. Mater. Sci. 15 (1980) 2258.

[31] K.K. Hansen, K.V. Hansen, Solid State Ionics 178 (2007) 1379.

[32] W. Zhou, R. Ran, Z.P. Shao, W. Zhuang, J. Jia, H.X. Gu, W.Q. Jin, N.P. Xu, Acta Mater. $56(2008) 2687$.

[33] J.D. Kim, G.D. Kim, J.W. Moon, Y. Park, W.H. Lee, K. Kobayashi, M. Nagai, C.E. Kim, Solid State Ionics 143 (2001) 379. 